\title{
The Susceptibility of Brassica Callus to Infection by Peronospora parasitica
}

\author{
By D. S. INGRAM \\ Botany School, Downing Street, Cambridge, CB2 3 EA \\ (Accepted for publication 9 July 1969)
}

\begin{abstract}
SUMMARY
Axenic combinations of Peronospora parasitica and callus of Brassica oleracea var. capitata, Drumhead cabbage, and other Brassica species were established. The fungus grew well in callus culture and sometimes had many of the characteristics of an aggressive parasite, in contrast with its growth habit in intact Brassica cotyledons. The susceptibility of different Brassica callus clones and root organ cultures to $P$. parasitica was not constant, and results obtained with callus were frequently at variance with results obtained using intact Brassica plant parts.
\end{abstract}

\section{INTRODUCTION}

Combinations of obligate parasites and host callus cultures suitable for experimental study have been achieved only by Morel (1944, 1948) with Plasmopara viticola and vine; by Hotson \& Cutter (I95I) and Cutter (1959) with Gymnosporangium juniperivirginianae and juniper; by Cutter (1960) with Uromyces ari-triphylli and Arisaema triphyllum; by Strandberg, Williams \& Yukawa (1966) and Ingram (1969a, b) with Plasmodiophora brassicae and Brassica. Most other combinations, including the downy mildew Peronospora tabacina and Nicotiana tabacum combination of Izard, Lacharpagne \& Schiltz (1964) have been short lived (Brian, 1967). Nakamura (1965) reported briefly on the dual culture of Peronospora parasitica and turnip. Cultures of Pseudoperonospora humuli and hop callus (Griffin \& Coley-Smith, I968) grew very slowly, and their use as experimental tools was thus precluded.

The expression of resistance to fungi in tissue culture has been investigated by Ingram \& Robertson (1965), Ingram (1966, 1967) and Robertson et al. (1968) using the Phytophthora infestans + Solanum tuberosum combination. In addition, Maheshwari, Hildebrandt \& Allen (1968) have studied abnormal resistance of Antirrhinum callus to infection by Puccinia antirrhini spores.

Methods for the successful growth of Peronospora parasitica in Brassica callus are reported here, together with some observations on the susceptibility and resistance of various callus clones of three Brassica species to invasion by $P$. parasitica.

\section{METHODS}

Organisms. Peronospora parasitica (Pers. ex Fr.) Fr. was isolated from leaves of Brassica oleracea var. gemmifera, Sutton's Fillbasket Brussels sprout, plants collected in Cambridge. Conidia were produced abundantly on the surface of detached leaves incubated for $72 \mathrm{hr}$ in a moist chamber in a cold frame, and a suspension containing about $3 \times 10^{5}$ conidia $/ \mathrm{ml}$. water was prepared. Drops ( $0.1 \mathrm{ml}$.) of suspension were 
applied to the upper surfaces of cotyledons from 7- to 9-day-old B. oleracea var. capitata, Early Drumhead or Primo cabbage, seedlings. These cotyledons had previously been removed in pairs, together with a $1 \cdot 5 \mathrm{~cm}$. length of hypocotyl, from seedlings which had been soil-grown in a greenhouse at $20^{\circ}$ to $25^{\circ}$, having supplementary lighting for $\mathrm{I} 2 \mathrm{hr}$ each day from six $125 \mathrm{~W}$ daylight fluorescent tubes. The cotyledon pairs were laid out in rows on moist filter paper (crinkled grey) contained in $17 \mathrm{~cm} . \times$ I I cm. $\times 4 \mathrm{~cm}$. clear plastic boxes, and were incubated, after inoculation, in an incubator at $15^{\circ}$ lit for $12 \mathrm{hr}$ each day by six $8 \mathrm{~W}$ warm white fluorescent tubes. This procedure was a modification of a method reported by Channon \& Hampson (1968).

Table I. Details of Brassica callus tissue cultures used in infection studies with Peronospora parasitica

\begin{tabular}{|c|c|c|c|c|}
\hline Parent species & $\begin{array}{l}\text { Origin of the } \\
\text { tissue culture }\end{array}$ & $\begin{array}{c}\text { Clone } \\
\text { no. }\end{array}$ & $\begin{array}{c}\text { Date of } \\
\text { establishment }\end{array}$ & $\begin{array}{l}\text { Characteristics } \\
\text { of callus }\end{array}$ \\
\hline \multirow{2}{*}{$\begin{array}{l}\text { B. oleracea } \\
\text { var. capitata } \\
\text { (Early Drum- } \\
\text { head cabbage) }\end{array}$} & $\begin{array}{l}\text { Surface sterilized } \\
\text { mature leaf }\end{array}$ & CL & Sept. I966 & $\begin{array}{l}\text { Slow growing } \\
\text { firm white callus }\end{array}$ \\
\hline & $\begin{array}{l}\text { Root from a 7-day } \\
\text { sterile seedling }\end{array}$ & $\mathrm{CR}$ & Sept. I966 & $\begin{array}{l}\text { Slow growing, } \\
\text { friable, mucila- } \\
\text { genous callus of } \\
\text { discreet meristem- } \\
\text { atic centres }\end{array}$ \\
\hline \multirow[t]{4}{*}{$\begin{array}{l}\text { B. rapa } \\
\text { (Golden Ball } \\
\text { turnip) }\end{array}$} & $\begin{array}{l}\text { Surface sterilized } \\
\text { expanded root/hypocotyl } \\
\text { from a 9-week plant }\end{array}$ & $\mathrm{GBC}_{\mathrm{I}}$ & Nov. 1966 & $\begin{array}{l}\text { Fast growing, firm } \\
\text { orange coloured } \\
\text { callus }\end{array}$ \\
\hline & $\begin{array}{l}\text { Surface sterilized } \\
\text { Plasmodiophora brassicae } \\
\text { clubbed root of a } \\
\text { 9-week plant }\end{array}$ & GBB 5 & Nov. 1966 & $\begin{array}{l}\text { Fast growing, dry, } \\
\text { friable callus }\end{array}$ \\
\hline & $\begin{array}{l}\text { Surface sterilized } \\
\text { expanded root/hypocotyl } \\
\text { from a } 5 \text {-week plant }\end{array}$ & $\mathrm{GB}(\mathrm{H})$ & July 1967 & $\begin{array}{l}\text { Fast growing, firm, } \\
\text { orange coloured } \\
\text { callus }\end{array}$ \\
\hline & $\begin{array}{l}\text { Surface sterilized } \\
\text { Plasmodiophora brassicae } \\
\text { clubbed root of a } \\
\text { 5-week plant }\end{array}$ & $\mathrm{GB}(\mathrm{i})$ & July 1967 & $\begin{array}{l}\text { Fast growing, firm, } \\
\text { orange coloured } \\
\text { callus }\end{array}$ \\
\hline \multirow[t]{2}{*}{$\begin{array}{l}\text { B. napus } \\
\text { (Wilhelms- } \\
\text { burger swede) }\end{array}$} & $\begin{array}{l}\text { Surface sterilized } \\
\text { expanded root/hypocotyl } \\
\text { from a 9-week plant }\end{array}$ & DG & Sept. 1966 & $\begin{array}{l}\text { Fast growing, dry, } \\
\text { friable orange } \\
\text { coloured callus }\end{array}$ \\
\hline & $\begin{array}{l}\text { Hypocotyl from a } 7 \text {-day } \\
\text { sterile seedling }\end{array}$ & DH & Nov. 1966 & $\begin{array}{l}\text { Fast growing, firm, } \\
\text { orange coloured } \\
\text { callus }\end{array}$ \\
\hline
\end{tabular}

Sporulation of Peronospora parasitica occurred after 5 to 8 days of incubation and conidia were used to inoculate a new batch of cotyledons. Non-sterile stock cultures of the fungus were maintained by transfer to fresh cotyledons every 7 days.

Callus culture clones were established from organs of Brassica oleracea var. capitata, Early Drumhead cabbage, B. rapa, Golden Ball turnip, and B. napus, Wilhelmsburger swede, as shown in Table I and according to the methods of Ingram (I969a). The callus culture medium was supplemented with 2,4-dichlorophenoxyacetic acid 6.0 mg./1., $\alpha$-naphthylacetic acid 0.I mg./1. and coconut milk I $50 \mathrm{ml}$./1. (Ingram I969a). 
Stock callus cultures were incubated at $25^{\circ}$ in the dark, but callus cultures infected with Peronospora parasitica were incubated either at $22^{\circ}$ in the dark or in the $15^{\circ}$ illuminated incubator described above. All callus experiments were made with $20 \mathrm{ml}$. of medium solidified with $0.6 \%$ Davis agar and contained in $25 \mathrm{~mm} . \times 150 \mathrm{~mm}$. Pyrex glass test tubes.

Root organ cultures were established from 7-day sterile seedlings of Brassica oleracea var. capitata, Drumhead and Primo, and B. rapa, Golden Ball, in a liquid medium (Street \& Henshaw, 1966) supplemented with meso-inositol $50 \cdot 0 \mathrm{mg} . / \mathrm{l}$., kinetin $0.00125 \mathrm{mg}$./1. and $\alpha$-naphthylacetic acid $0.00005 \mathrm{mg}$./1. (Ingram I969a).

Establishment of Peronospora parasitica in callus culture. Cotyledon pairs from 7-day Brassica oleracea var. capitata, Drumhead, seedlings were inoculated with conidia of Peronospora parasitica and incubated at $15^{\circ}$ as described above. After $72 \mathrm{hr}$ the cotyledons were detached from the hypocotyl segments, washed in $95 \%(\mathrm{v} / \mathrm{v})$ ethanol in water and surface sterilized for $5 \mathrm{~min}$. in a $5 \%(\mathrm{w} / \mathrm{v})$ filtered calcium hypochlorite solution containing a drop of detergent. After three washes in sterile distilled water each cotyledon was cut in half and the halves placed upper-side downwards on solidified callus culture medium in test tubes and incubated at $22^{\circ}$ in the dark. Cotyledon halves which remained sterile and gave rise to aerial mycelium of $P$. parasitica were placed on the surface of growing $B$. oleracea var. capitata, Drumhead, leaf calluses in culture tubes and were further incubated at $22^{\circ}$.

Histological procedures. Calluses and detached cotyledons infected with Peronospora parasitica were fixed in glutaraldehyde and embedded in wax (Ingram, I969a). Sections (I6 $\mu$ ) were stained with Delafield's haematoxylin (Ingram, I967); or with resorcin blue (Griffin \& Coley-Smith, I968); or with safranin-O (ethanolic safranin-O I. O g. + Cellosolve (2-ethoxyethanol) $50.0 \mathrm{ml} .+95 \%$ ethanol in water $25.0 \mathrm{ml} .+$ sodium acetate $\mathrm{r} \cdot 0 \mathrm{~g}$. + formalin $2.0 \mathrm{ml}$. + distilled water $25.0 \mathrm{ml}$.) for $30 \mathrm{~min}$. followed by a wash in running water, counterstaining in fast green $(0.5 \%$ in equal volumes clove oil, absolute ethanol and Cellosolve) for ro sec., a wash in clove oil and $5 \mathrm{~min}$. in a clearing mixture ( 50 vol. clove oil +25 vol. absolute ethanol +25 vol. xylene). Small pieces of fresh infected callus were also examined whole or as freehand sections or squashes.

Infection test with Brassica plant parts. The detached cotyledon technique described above was used to test the susceptibility of Brassica rapa, Golden Ball, and B. napus Wilhelmsburger, cotyledons to Peronospora parasitica. Conidia obtained from detached cotyledons of Brassica oleracea var. capitata, Drumhead, infected with $P$. parasitica were used as inoculum. When the susceptibility of seedling roots or hypocotyls was to be tested the technique was modified: washed 7-day seedlings were laid out in the plastic boxes instead of detached cotyledon pairs. Tests were replicated 20 times and were repeated. In one test the susceptibility of root/hypocotyl slices from mature plant of Brassica rapa, Golden Ball, and B. napus, Wilhelmsburger, was investigated. Plants of these two species were raised in soil in the greenhouse and were harvested at 9 weeks. The swollen root/hypocotyls were washed thoroughly in water, surface sterilized by immersion in a $5 \%$ filtered calcium hypochlorite solution for $10 \mathrm{~min}$. and washed twice in sterile distilled water. Slices, $0.5 \mathrm{~cm}$. thick, were laid on moist sterile filter paper in Petri plates. The slices were each inoculated at the centre with $0 \cdot \mathrm{I} \mathrm{ml}$. of a suspension containing $3 \times 10^{4}$ conidia of $P$. parasitica and were incubated in the $15^{\circ}$ illuminated incubator. 
The pathogenicity of callus grown Peronospora parasitica to cotyledons of Brassica oleracea var. capitata, Drumhead, was tested using the detached cotyledon techniques where a conidial suspension obtained from an infected callus culture of $B$. rapa, clone GBC I, was substituted for the cotyledon-produced conidia, or where explants $\left(3^{\circ} \circ\right.$ $\mathrm{mm}^{3}$ ) of infected $B$. rapa, clone GBCr, callus and $B$. oleracea var. capitata, Drumhead, leaf callus were applied in $0.05 \mathrm{ml}$. drops of water to the upper surfaces of cotyledons. The callus fragments were removed from the cotyledons after $24 \mathrm{hr}$.

Infection tests with tissue cultures to assess the ability of Peronospora parasitica to colonize callus of the Brassica clones listed in Table I were carried out by placing an explant $\left(3.0 \mathrm{~mm}^{3}\right)$ of Brassica rapa, clone $\mathrm{GBC} \mathrm{I}$, callus, permeated with mycelium of $P$. parasitica, on the surface of the culture medium and in contact with a freshly transferred callus of the clone to be tested. Incubation was then at $22^{\circ}$ in the dark. Alternatively, calluses were each inoculated with $0.1 \mathrm{ml}$. of a sterile suspension containing $10^{3}$ conidia $/ \mathrm{ml}$. distilled water, obtained from infected cultures of $B$. rapa, clone GBCI, and were incubated at $15^{\circ}$ in the dark for $48 \mathrm{hr}$ and then at $22^{\circ}$ in the dark.

Root organ culture infection tests were made by using $4^{\circ} \mathrm{ocm}$. root tip segments, from liquid culture, placed on the surface of the organ culture medium solidified with $0.6 \%$ Davis agar and contained in Petri plates. Each root segment was inoculated with $0.1 \mathrm{ml}$. of a sterile suspension containing $10^{3}$ conidia $/ \mathrm{ml}$. sterile water, obtained from infected calluses of Brassica rapa, clone GBCI. Incubation was at $15^{\circ}$ in the dark for $48 \mathrm{hr}$ and then at $22^{\circ}$ in the dark.

All infection tests with calluses and organ cultures were replicated at least five times and were repeated twice.

\section{RESULTS AND DISCUSSION}

\section{Establishment of Peronospora parasitica in callus culture}

Aerial mycelium of Peronospora parasitica developed abundantly on seven out of I6 infected surface-sterilized cotyledons of Brassica oleracea var. capitata, Drumhead, incubated on callus medium at $22^{\circ}$ in the dark for 5 days. The cotyledons became yellow during this time, but remained turgid. Aerial mycelium did not develop on eight of the cotyledons and one became contaminated with bacteria. When half cotyledons covered with aerial mycelium were placed in contact with six root calluses and seven leaf calluses of $B$. oleracea var. capitata, Drumhead, contaminant bacteria developed on one root callus and on four leaf calluses. $P$. parasitica from the cotyledon halves did not invade the root calluses, but did invade and became established in the three uncontaminated leaf calluses. After 14 days of incubation at $22^{\circ}$ in the dark the latter were brown and moribund and were covered with aerial mycelium of the fungus; the cotyledon inoculum had withered completely.

Leaf callus infected with Peronospora parasitica could not be subcultured to fresh medium since the infected tissues aged rapidly. In contrast, healthy leaf callus could be subcultured readily and proliferated well on fresh medium. It is regrettable that the infected calluses could not be transferred directly, since this would have facilitated their use as experimental tools. Sterile fungus + callus combinations could be perpetuated, however, by inoculation of fresh, uninfected calluses with a $3.0 \mathrm{~mm} .^{3}$ explant of infected tissue from a moribund culture, and incubation at $22^{\circ}$ in the dark. Fungus 
hyphae usually grew from the inoculum and invaded the new tissue after about seven days. Cultures of $\boldsymbol{P}$. parasitica on Brassica oleracea var. capitata leaf callus were maintained by inoculation of fresh tissues ever 14 to $2 \mathrm{I}$ days. It was later found more convenient to substitute the faster growing B. rapa, clone GBC I, callus for the $B$. oleracea var. capitata tissue. Fungus + clone GBC I callus combinations were usually maintained by inoculation of fresh calluses with explants from moribund cultures as described above. However, infected clone GBC I calluses could also be transferred directly: about 4 weeks after infection of GBC I calluses with $P$. parasitica, by which time cultures were brown and apparently senescent, small nodules of new tissue began to arise on the callus surface and frequently became infected by the fungus. These new infected tissues could be removed to fresh medium where they proliferated, or the whole callus could be transferred and the nodules allowed to grow to form larger masses of tissue. The nodules, which sections showed were formed from deep-seated uninfected layers of cells, sometimes did not become infected by $P$. parasitica. The phenomenon of re-growth of the infected clone GBC I calluses might have useful applications.

Conidia of Peronospora parasitica were not produced readily on callus cultures incubated at $22^{\circ}$ in the dark, but were produced abundantly on infected calluses transferred to the $15^{\circ}$ illuminated incubator, particularly when $0.5 \mathrm{ml}$. of sterile distilled water was applied to the surface of the culture medium. Davison (1968) commented on the effects of light on sporulation of $P$. parasitica. However, it is not possible to draw definite conclusions from the observations reported here, except to comment that conditions in the $15^{\circ}$ illuminated incubator probably resembled more closely the natural conditions for growth and sporulation of $P$. parasitica than did conditions in the $22^{\circ}$ dark incubator. The conidia formed on callus were typical of $P$. parasitica (Pl. I, fig. I, 2) and were pathogenic to detached cotyledons of Brassica oleracea var. capitata, Drumhead, or leaf callus of this species or callus of $B$. rapa, clone GBC I. On inoculated calluses and on cotyledons, typical $P$. parasitica conidial heads were produced after 5 to 8 days of incubation at $15^{\circ}$ in the illuminated incubator. Moreover, explants of moribund infected callus were capable of infecting detached Drumhead cotyledons, leading to formation of conidia. At no time were spores similar to the spores of any fungus other than $P$. parasitica observed on infected calluses.

Peronospora parasitica maintained in callus culture was always restricted to the callus tissue, and hyphae did not make any growth on to the surrounding culture medium. This is in contrast to the findings of Griffin \& Coley-Smith (1968), who showed that Pseudoperonospora humuli frequently grew for short distances away from hop calluses on the culture medium.

\section{Histological investigation of infected calluses}

The growth habit of Peronospora parasitica was compared in detached cotyledons of Brassica oleracea var. capitata, Drumhead, and in callus of B. oleracea var. capitata, Drumhead leaf and of $B$. rapa, clone GBCI. At the time of fixation, cotyledons infected with $P$. parasitica had a dense cover of conidiophores bearing conidia. Infected calluses were covered with a layer of sterile aerial hyphae.

Detached cotyledons of Brassica oleracea var. capitata, Drumhead were fixed 7 days after infection, and sections cut in a near-paradermal plane. Mycelium in the cotyle- 
dons was diffuse and predominantly intercellular, with hyphae present in all tissues except the xylem. Individual hyphae were between $10 \cdot 0 \mu$ and $16 \cdot 0 \mu$ diameter. Haustoria were present and were normally simple, flask shaped and about II $0 \mu$ wide by $22 \cdot 0 \mu$ long (Pl. I, fig. 3, 4); bilobed haustoria were occasionally noted. A callose haustorial sheath, which stained blue with resorcin blue, was often present. Between one and four haustoria were present in each penetrated host cell. These findings were in agreement with the findings of Fraymouth (1956). Conidiophores usually emerged in groups of three to eight through stomata on both surfaces of the cotyledons; oospores were not noted. There was no evidence that $P$. parasitica had killed or macerated host cells.

Leaf callus of Brassica oleracea var. capitata, Drumhead, was fixed 7 days after infection. The distribution of mycelium in callus tissues was quite different from that in detached cotyledons. The outer layer (three or four cells deep) of each callus had been heavily invaded by coenocytic hyphae which were both inter- and intra-cellular. Cells in this layer were frequently packed with hyphae or with enlarged and swollen haustoria (Pl. 2, fig. 5, 6), while individual haustoria were often compound, having two to four branches (PI. 2, fig. 7). In many cases it was impossible to determine whether cells were filled with enlarged haustoria or with intracellular hyphae. Butler \& Jones (196I) figured a similar aggressive growth habit of Peronospora parasitica in stems of Capsella bursa-pastoris. Below the outer layer of heavily invaded Drumhead cells occurred another layer, also three to four cells thick, where growth of $P$. parasitica was more diffuse, hyphae tending towards an intercellular growth habit with cells penetrated by smaller, simple or bilobed haustoria. The central regions of infected calluses were completely free of mycelium. This could have been due to a decreased availability of oxygen in the deeper seated tissues or to the fact that the central regions of calluses usually consisted of dead or old cells.

Calluses of Drumhead leaf fixed 2 I days after infection with Peronospora parasitica were also examined. These calluses were brown in colour and were completely senescent. Fungus distribution was the same as in 7-day infected calluses. However, all heavily invaded tissues were quite dead and individual cell walls were thickened and golden brown in colour. These thickened walls did not take up Delafield's stain.

Calluses of Brassica rapa, clone $G B C r$ were fixed 7 days after infection. The distribution of hyphae was similar to that in Drumhead leaf calluses, infection being restricted to the outer layers of cells, with the central region free from the parasite. An important difference, however, was that in the clone GBC I calluses hyphae were predominantly intercellular, and only occasionally intracellular. Moreover, haustoria resembled the haustoria found in Drumhead cotyledons, being restricted in size and only occurring in groups of one to three per cell. A sheath was frequently present and both simple and bi- and trilobed haustoria were found (Pl. 2, fig. 8). Oospores were not detected in callus cultures, and there was no evidence for tissue maceration.

Clearly, Peronospora parasitica had a more aggressive growth habit in the Brassica cleracea var. capitata leaf calluses than in the $B$. rapa, clone $\mathrm{GBC}$, calluses and the $B$. oleracea var. capitata cotyledons. It is likely that the vigour of fungal growth in callus is related both to the physiological state of the calluses at the time of inoculation and to the sources from which the fungal cultures and the callus cultures are derived. 


\section{Infection tests}

Tests with detached plant parts. The results of these tests are summarized in Table 2. The isolate of Peronospora parasitica used in the experiments was pathogenic to, and became systemic in, detached cotyledons or whole seedlings of Brassica oleracea var.

\section{Table 2. Growth of Peronospora parasitica on callus tissues and detached plant parts of three Brassica species}

Inoculum consisted of explants of $B$. rapa, clone GBC I, callus infected with $P$. parasitica in the callus tests, and conidia from cotyledons of $B$. oleracea var. capitata, Drumhead, in the detached plant part tests.

Growth of $P$. parasitica on test calluses: $+++=$ aerial mycelium covering the whole callus in 7 to 14 days; $++=$ aerial mycelium covering the whole callus in 14 to 21 days; $+=$ invasion of callus not occurring until 4 weeks after infection, and then being restricted; $-=$ callus not invaded. Susceptibility of detached organs: $\mathbf{S}=$ susceptible; $\mathbf{H}=$ hypersensitive reaction; $\mathbf{R}=$ resistant. N.T. $=$ not tested.

\begin{tabular}{|c|c|c|c|c|c|}
\hline \multirow[b]{2}{*}{ Brassica species } & \multirow[b]{2}{*}{ Plant part } & \multicolumn{3}{|c|}{ Callus tissues } & \multirow{2}{*}{$\begin{array}{l}\text { Plant parts } \\
\text { Resistance or } \\
\text { susceptibility }\end{array}$} \\
\hline & & $\begin{array}{l}\text { Callus } \\
\text { clone no. }\end{array}$ & $\begin{array}{r}\text { Growth of } \\
P . \text { parasitica }\end{array}$ & $\begin{array}{l}\text { Time } \\
\text { to onset of } \\
\text { senescence of } \\
\text { callus } \\
\text { (days) }\end{array}$ & \\
\hline \multirow[t]{3}{*}{$\begin{array}{l}\text { B. oleracea var. } \\
\text { capitata, Early } \\
\text { Drumhead cabbage }\end{array}$} & $\begin{array}{l}\text { Mature leaf } \\
\text { Seedling } \\
\text { cotyledon }\end{array}$ & $\begin{array}{l}\text { CL } \\
\text { N.T. }\end{array}$ & $\begin{array}{l}+++ \\
\text { N.T. }\end{array}$ & $\begin{array}{l}\text { I } 4< \\
\text { N.T. }\end{array}$ & $\begin{array}{l}\text { N.T. } \\
\mathbf{S}^{*}\end{array}$ \\
\hline & $\begin{array}{l}\text { Seedling } \\
\text { hypocotyl }\end{array}$ & N.T. & N.T. & N.T. & $\mathbf{S}^{*}$ \\
\hline & Seedling root & CR & - & $56<$ & $\mathbf{S}^{*}$ \\
\hline \multirow[t]{7}{*}{$\begin{array}{l}\text { B. rapa, Golden Ball } \\
\text { turnip }\end{array}$} & $\begin{array}{l}\text { Mature root/ } \\
\text { hypocotyl }\end{array}$ & GBC I & +++ & $I 4-2 I<$ & $\mathbf{S}$ \\
\hline & $\begin{array}{l}\text { Mature root/ } \\
\text { hypocotyl }\end{array}$ & $\mathbf{G B}(\mathrm{H})$ & $\left.\begin{array}{r}++ \\
++\end{array}\right\}$ & $14<$ & \\
\hline & $\begin{array}{l}\text { Plasmodio- } \\
\text { phora } \\
\text { brassicae- } \\
\text { clubbed root }\end{array}$ & GBB 5 & - & $56<$ & N.T. \\
\hline & $\begin{array}{l}\text { Plasmodio- } \\
\text { phora } \\
\text { brassicae- } \\
\text { clubbed root }\end{array}$ & GB(i) & +++ & $28<$ & N.T. \\
\hline & $\begin{array}{l}\text { Seedling } \\
\text { cotyledon }\end{array}$ & N.T. & N.T. & N.T. & $\mathbf{H}$ \\
\hline & $\begin{array}{l}\text { Seedling } \\
\text { hypocotyl }\end{array}$ & N.T. & N.T. & N.T. & $\mathbf{H}$ \\
\hline & Seedling root & N.T. & N.T. & N.T. & $\mathbf{R}$ \\
\hline \multirow[t]{3}{*}{$\begin{array}{l}B \text {. napus, Wilhelms- } \\
\text { burger swede }\end{array}$} & $\begin{array}{l}\text { Mature root/ } \\
\text { hypocotyl }\end{array}$ & DG & + & $2 I-28<$ & $\mathbf{S}$ \\
\hline & $\begin{array}{l}\text { Seedling } \\
\text { cotyledon }\end{array}$ & N.T. & N.T. & N.T. & $\mathbf{H}$ \\
\hline & $\begin{array}{l}\text { Seedling } \\
\text { hypocotyl } \\
\text { Seedling root }\end{array}$ & DH & $\left.\begin{array}{r}++ \\
++ \\
\pm \\
\mathbf{T}\end{array}\right\}$ & $14<$ & $\mathbf{H}$ \\
\hline
\end{tabular}

\footnotetext{
* Infection of these tissues also occurred systemically.
} 
capitata, Drumhead and Primo, irrespective of whether the conidial inoculum was applied to the roots, the hypocotyls or the cotyledons. Normally all seedlings in these tests were susceptible. It was not possible to infect roots, hypocotyls or cotyledons of B. rapa, Golden Ball, or B. napus, Wilhelmsburger, seedlings successfully with a conidial inoculum of $P$. parasitica. Attempted infection of Golden Ball and Wilhelmsburger cotyledons and hypocotyls led to necrotic flecking characteristic of a hypersensitive reaction. Occasionally, when Wilhelmsburger cotyledons under test were becoming senescent a few sparse conidiophores of $\boldsymbol{P}$. parasitica were produced, but this was not a normal occurrence. In contrast, when a conidial suspension was applied to mature root/hypocotyl slices of Golden Ball and Wilhelmsburger, the fungus rapidly became established in the tissues and sporulation occurred within 7 days. Infection always took place, irrespective of whether tissue slices were taken from the apical or the basal ends of the roots.

Host specificity did appear to be expressed by the Peronospora parasitica, a finding which is in keeping with the work of Natti, Dickson \& Atkin (1967), who identified two physiological races of the fungus and demonstrated the existence of two dominant resistance genes in Brassica oleracea. The anomalous results obtained with the Golden Ball and Wilhelmsburger root slices may have been due to the fact that conidia were applied to cut rather than intact tissue surfaces.

Tests with callus tissues. The result of tests to assess the ability of Peronospora parasitica to invade various Brassica callus tissues are summarized in Table 2. (Fragments of tissue from an infected Brassica rapa clone GBCI callus were used as inoculum.) Invasion of calluses was assessed on the basis of aerial mycelium production and examination of hand sections.

Peronospora parasitica did not invade callus of Brassica rapa, Golden Ball, clone GBB 5 root/hypocotyl (already infected with Plasmodiophora brassica plasmodia) or of $B$. oleracea var. capitata, Drumhead, root. There was no evidence that a diffusible inhibitor was produced by the resistant calluses, for aerial mycelium was always produced on the inoculum explants in contact with the tissues under test. Calluses of $B$. napus, Wilhelmsburger, clone DG, root were only invaded when the tissues were becoming less vigorous, about 3 to 4 weeks after inoculation. Such invasions were restricted to an area about $5.0 \mathrm{~mm}$. diameter around the point of contact between the inoculum and the test callus: this area enlarged as the calluses senesced. Infection was accompanied by darkening of the tissues.

Calluses of Wilhelmsburger seedling hypocotyl, clone $\mathrm{DH}$, did not give consistent results in infection tests: some cultures were susceptible and were invaded by Peronospora parasitica in 7 to 14 days, although invasion was accompanied by browning of the infected tissues and senescence of the calluses by 14 days. Other clone DH calluses were less susceptible and were frequently only partially invaded by the fungus. The uninfected remainders of such calluses usually continued to grow and did not senesce until 6 to 8 weeks old. Yet other clone DH calluses were totally resistant and never became invaded by $P$. parasitica, although the fungus proliferated on the inoculum explants. Brassica rapa, Golden Ball, clone $\mathrm{GB}(\mathrm{H})$, also gave inconsistent results, some calluses being susceptible to invasion by $P$. parasitica, and others being only partly susceptible or completely resistant.

Calluses of Brassica oleracea var. capitata, Drumhead, leaf and B. rapa, Golden Ball, root/hypocotyl clones GB(i) (already infected with plasmodia of Plasmodiophora 
brassicae) and $\mathrm{GBC}_{\mathrm{I}}$ were consistently susceptible to Peronospora parasitica, and were completely covered with mycelium 7 days after infection. Senescence occurred most readily in the slow-growing Drumhead leaf calluses, beginning at about 14 days, when calluses became brown and growth stopped. Senescence of clone GBC I calluses infected with $P$. parasitica was slower to begin, while senescence of infected clone GB(i) calluses did not begin until 28 days after infection. Senescence of uninfected calluses did not usually occur until they were 6 to 8 weeks old. Re-growth of Golden Ball clones $G B C$ I, GB(H) and GB(i) calluses, in the form of small tissue nodules which proliferated and became infected with $P$. parasitica, occurred at 4 weeks after infection.

When Brassica oleracea var. capitata, Drumhead, leaf and root calluses and $B$. rapa clone GBCI calluses were inoculated with $0.1 \mathrm{ml}$. of a suspension containing $10^{3}$ Peronospora parasitica conidia $/ \mathrm{ml}$., the fungus became established in the Drumhead leaf calluses and in the GBC I calluses, but infection of Drumhead root calluses did not occur.

Tests with root organ cultures. It was thought that root organ cultures might resemble intact plants more closely than callus in their response to infection by Peronospora parasitica. This was not so, however. Direct microscopic examination of Petri plate cultures 14 days after inoculation showed that $P$. parasitica conidia had germinated on, and in contact with, root hairs and roots of Brassica oleracea var. capitata, Drumhead and Primo, and of B. rapa, Golden Ball. However, infection of the roots did not normally occur. Limited invasion of two of the Primo root cultures took place, and hyphae could be seen growing for short distances on the root surfaces. These infections did not develop and the fungus did not sporulate. In those cultures of Drumhead, Primo and Golden Ball where penetration had not taken place there was no evidence that spore germination had been inhibited by the root organ cultures or that germ tubes were orientated either away from or towards the roots.

It is quite clear that the expression of resistance to Peronospora parasitica in callus culture and in root organ culture is variable and cannot be related directly to findings with intact plants. This is in contrast to the work of Ingram and Robertson (1965) and Ingram (1966, 1967), who found good correlation between intact plants and tissue cultures of Solanum tuberosum in the expression of R-gene resistance to Phytophthora infestans. Maheshwari et al. (1968) demonstrated production of an abnormal metabolite by Antirrhinum callus which was toxic to Puccinia antirrhini. Abnormal antimicrobial metabolite production by callus of lettuce and cauliflower (Campbell, Chan \& Barker, 1965) and by callus of Populus tremula (Mathes, 1963) has also been demonstrated. It is possible that a similar phenomenon may have been operative in the abnormally resistant Brassica oleracea var. capitata root calluses. The unexpected susceptibility of many of the B. rapa, Golden Ball, and B. napus, Wilhelmsburger, calluses to $P$. parasitica is difficult to explain, although it is significant that root slices of these two species were susceptible to the fungus, and like calluses were inoculated on surfaces not possessing an epidermis. It may also be relevant that Ingram (I966) and Robertson et al. (I968) observed a decrease in the resistance of $S$. tuberosum calluses to $P$. infestans which could be correlated with the length of time that the tissues had been in culture: all of the Brassica callus cultures used in the tests described here had been in culture for more than one year. It is possible that freshly isolated calluses would behave in a similar way to intact plants in response to infection with $P$. parasitica. 
The results of the infection tests serve to emphasize the caution necessary in relating results obtained on the growth of fungi in tissue culture to their growth in intact plants.

I wish to thank the Agricultural Research Council or financial support, Professor P. W. Brian for advice and discussions and Dr H. J. Hudson for leaves of Brussels Sprout infected with Peronospora parasitica.

\section{REFERENCES}

BrIAN, P. W. (1967). Obligate parasitism in fungi. Proc. R. Soc. B 168, IOI.

ButLer, E. J. \& Jones, S. G. (I96I). Plant Pathology, p. 68. London: Macmillan \& Co. Ltd.

Campbell, G., Chan, E. C. S. \& Barker, W. G. (I965). Growth of lettuce and cauliflower tissues in vitro and their production of antimicrobial metabolites. Can. J. Microbiol. II, 785.

Channon, A. G. \& Hampson, R. J. (I968). Laboratory tests of fungicides against Peronospora parasitica (Pers. ex Fr.) Fr. Ann. appl. Biol. 62, 23.

CuTTER, V. M. (1959). Studies on the isolation and growth of plant rusts in host tissue cultures and upon synthetic media. I. Gymnosporangium. Mycologia 5I, 248.

CUTTER, V. M. (1960). Studies on the isolation and growth of plant rusts in host tissue cultures and upon synthetic media. II. Uromyces ari-triphylli. Mycologia 52, 726.

Davison, E. M. (1968). Development of sporangiophores of Peronospora parasitica (Pers. ex Fr.) Fr. Ann. Bot. 32. 623.

Fraymouth, J. (1956). Haustoria of the Peronosporales. Trans. Br. mycol. Soc. 39, 79.

Griffin, M. J. \& Coley-Smith, J. R. (I968). The establishment of Hop tissue cultures and their infection by Downy Mildew Pseudoperonospora humuli (Miy. \& Tak.) Wilson under aseptic conditions. J. gen. Microbiol. 53, 231.

Hotson, H. H. \& CUTTER, V. M. (I95I). The isolation and culture of Gymnosporangium juniperivirginianae Schw. Proc. natn. Acad. Sci. U.S.A. 37, 400.

Ingram, D. S. (1966). Interaction between Phytophthora infestans (Mont.) de Bary and tissue cultures of Solanum tuberosum L. Ph.D. Thesis, University of Hull.

INGRAM, D. S. (1967). The expression of R-gene resistance to Phytophthora infestans in tissue cultures of Solanum tuberosum. J. gen. Microbiol. 49, 99.

INGRAM, D. S. (I969a). Growth of Plasmodiophora brassicae in host callus. J. gen. Microbiol. 55, 9.

INGRAM, D. S. (1969b). Abnormal growth of tissues infected with Plasmodiophora brassicae. J. gen. Microbiol. 56, 55.

Ingram, D. S. \& Robertson, N. F. (1965). Interaction between Phytophthora infestans and tissue cultures of Solanum tuberosum. J. gen. Microbiol. 40, 43I.

Izard, C., Lacharpagne, J. \& Schiltz, P. (1964). Behaviour of Peronospora tabacina in tissue cultures, and role of the leaf epidermis. Annales de la Direction des Etudes et de l'Equipement. Service d'Exploitation Industrielle des Tabacs et des Allumettes (Section 2), p. 95.

Maheshwari, R., Hildebrandt, A. C. \& Allen, P. J. (1968). Factors affecting the growth of rust fungi on host tissue cultures. Bot. Gaz. 128, 153 .

Mathes, M. C. (1963). Antimicrobial substances from Aspen tissues grown in vitro. Science, N.Y. I40, I IOI.

Morel, G. (1944). Le développement du mildiou sur des tissus de Vigne cultures in vitro. C.r. hebd. Séanc. Acad. Sci., Paris 218, 50.

MOREL, G. (1948). Recherches sur la culture associée de parasites obligatoires et de tissus végétaux. Annales des Epiphyties Série Pathologie Végétale 14, I.

Nakamura, H. (1965). The use of tissue cultures in the study of obligate parasites. In Proc. int. Conf. Plant Tissue Culture, p. 535, Berkeley, California: McCutchan Publ. Co.

Natri, J. J., Dickson, M. H. \& ATKIN, J. D. (1967). Resistance of Brassica oleracea varieties to Downy Mildew. Phytopathology 57, 144.

Robertson, N. F., Friend, J., Aveyard, M., Brown, J., Huffee, M. \& Homans, A. L. (1968). The accumulation of phenolic acids in tissue culture pathogen combinations of Solanum tuberosum and Phytophthora infestans. J. gen. Microbiol. 54, 261. 
Journal of General Microbiology, Vol. 58, No. 3

Plate I
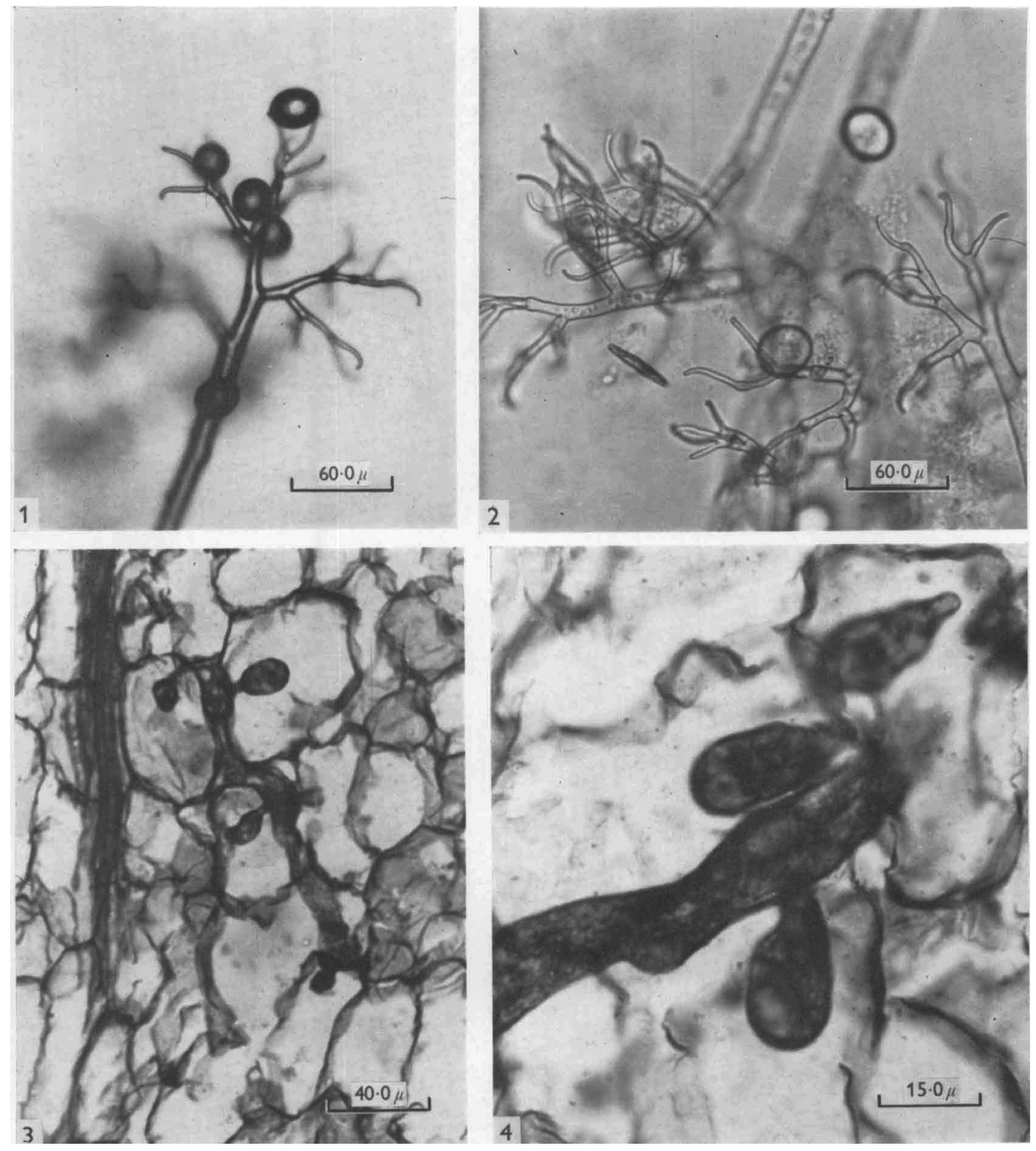

D. S. INGRAM

(Facing p. 400) : 
Journal of General Microbiology, Vol. 58, No. 3

Plate 2
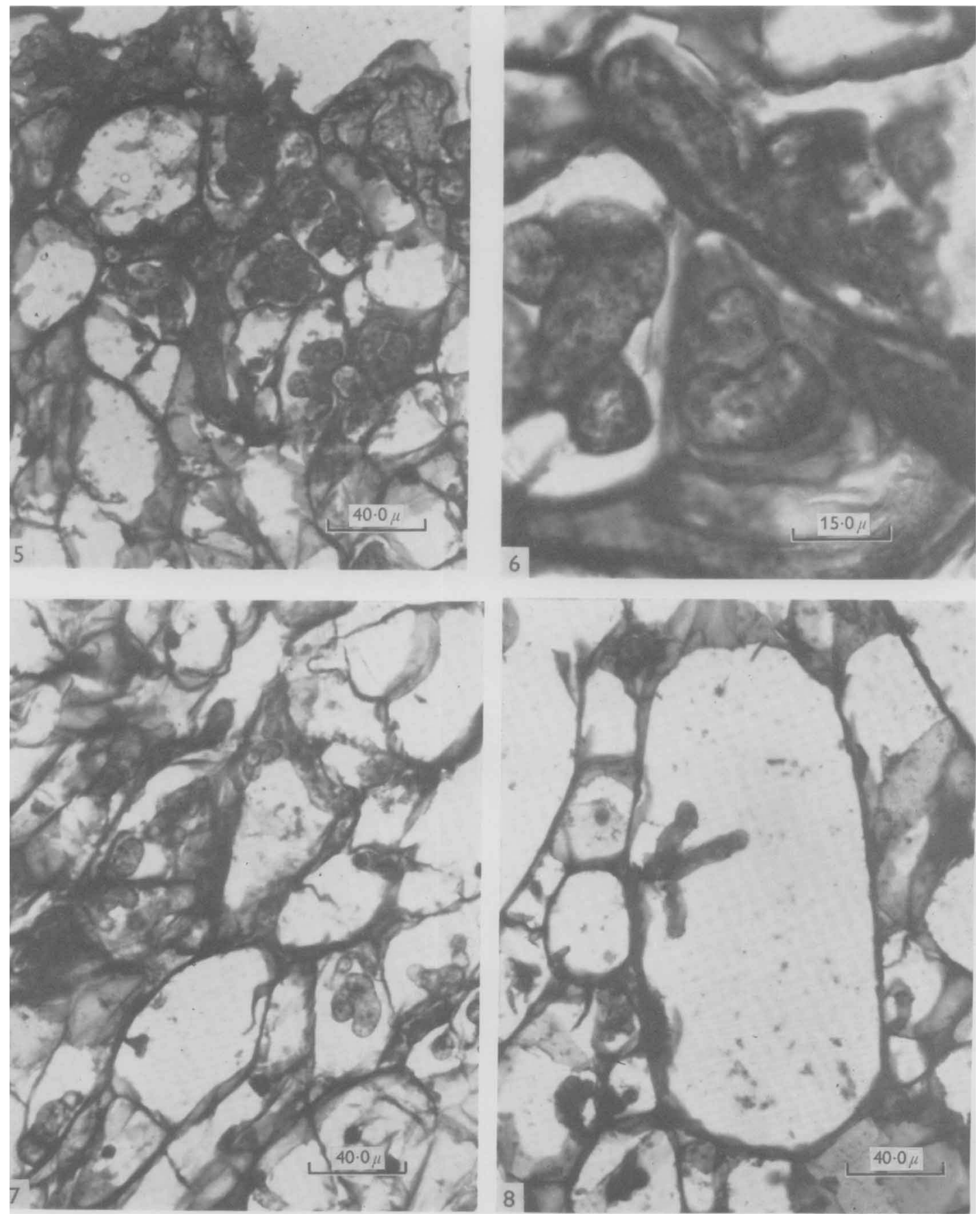

D. S. INGRAM 
Strandberg, J. O., Williams, P. H. \& Yukawa, Y. (I966). Monaxenic culture of Plasmodiophora brassicae with cabbage tissue. Phytopathology 56, 903 (abstract).

Street, H. E. \& HenshaW, G. G. (1966). Introduction and methods employed in plant tissue culture. In Cells and Tissues in Culture. Ed. by E. N. Willmer. Vol. 3, p. 459. London: Academic Press.

\section{EXPLANATION OF PLATES}

Plate I

Fig. I and 2. Typical conidia and conidiophores of Peronospora parasitica grown on Brassica rapa, clone GBCI, callus. Unstained (fig. I) and a squash stained with cotton blue (fig. 2).

Fig. 3 and 4. Intercellular hyphae and haustoria growing in a detached cotyledon of Brassica oleracea var. capitata, Drumhead cabbage. Near paradermal sections stained with Delafield's haematoxylin.

Plate 2

Fig. 5, 6 and 7. Inter- and intracellular hyphae and haustoria of Peronospora parasitica in Brassica oleracea var. capitata, Early Drumhead cabbage, leaf callus. Stained with Delafield's haematoxylin. Fig. 8. A three-lobed haustorium of Peronospora parasitica in an enlarged cell of Brassica rapa, clone GBC I, callus. Stained with Delafield's haematoxylin. 